УДК 347.122

DOI https://doi.org/10.32849/2663-5313/2020.2.10

\title{
Георгій Смірнов,
}

аспірант юридичного факультету

Київського начіонального університету імені Тараса Шевченка

\section{КОРПОРАТИВНІ ПРАВА: ПОНЯТТЯ ТА ПРАВОВА ПРИРОДА}

Стаття присвячена аналізу поняття та правової природи корпоративних прав. Автором досліджуються доктринальні підходи до розуміння об'єктивного та суб'єктивного корпоративного права, наводяться недоліки таких підходів та надаються власні визначення аналізованих понять. Висловлено незгоду з належністю корпоративних прав до особистих немайнових прав, оскільки відсутні ознаки останніх. Наголошено на відмінностях у набутті корпоративних прав, що випливають із частки у статутному капіталі й акцій товариства. В обох випадках ідеться про право власності як підставу для набуття корпоративних прав, проте що стосується акиій, то як право власності на них, так $i$ корпоративні права виникають одночасно - з моменту внесення відомостей до єдиної депозитарної системи. Досліджено явище «засновииького» права. Наголошено на неможливості віднесення його до корпоративних прав з огляду на виникнення останніх у зв'язку зі створенням юридичної особи. Однак відносини, пов'язані з реалізачією «засновнииького» права, слід вважати корпоративними. У статті також досліджено особливості іноземних законодавств щодо можливості існування «юридичних осіб у процесі створення», корпоративні права в яких можуть виникати до їх створення. Аналіз поняття та правової природи корпоративних прав здійснено також крізь призму такого явища, як номінальні учасники / акиіонери товариства. Зроблено висновок, що чинне законодавство демонструє фрагментарний підхід у врегулюванні даного феномену - з усіх господарських товариств лише в акиіонерних товариствах можна говорити про бенефіміарного власника як учасника корпоративних відносин. Саме тому запропоновано внести зміни до чинного законодавства, передбачивши визначення корпоративних прав через прив'язку не тільки до права власності, але й до опосередкованого його набуття, аналогічно з акиіонерними товариствами. Автор також розглядає питання правової природи корпоративних прав, зазначає змішаний характер останніх, хоч і виникнення даних прав зумовлено правом власності на частку / акиії. Також запропоновано розглядати корпоративні права з погляду їхньої множинності, а не єдиного корпоративного права, зміст якого становлять правомочності та субправомочності.

Ключові слова: корпоративні права, правомочності, засновницьке право, частка, акції, статутний капітал.

Постановка проблеми. Корпоративне законодавство України сьогодні перебуває в постійному розвитку, динаміка якого $€$ настільки високою, що часом суспільні відносини не встигають адаптуватися до тих змін, які їм диктує законодавець. У зв'язку із цим суспільство стикається з низкою теоретико-практичних питань, які потребують вирішення. Однак вирішення вищезазначених проблем потребує передусім грунтовного розуміння об'єкта корпоративних відносин - що ж саме собою являють корпоративні права, якою саме є їхня правова природа. Саме з'ясуванню змісту поняття корпоративного права та його правової природи і присвячена дана робота.

Аналізу поняття й особливостей правової природи корпоративних прав присвячували свої праці такі вчені, як: І.В. Спасибо-Фатєєва, М.К. Богуш, І.В. Лукач, А.Ю. Смітюх, О.В. Бігняк, О.Р. Кібенко, А.В. Сороченко,
I.T. Тарасов, В.М. Кравчук, Ю.С. Поваров, Ю.М. Жорнокуй, В.І. Цікало, В.А. Бєлов, С.В. Батрин, Н.С. Глусь, Т.В. Кашаніна й інші.

Метою статті $\epsilon$ розгляд поняття та правової природи корпоративних прав.

Виклад основного матеріалу. Розпочати дослідження поняття та правової природи корпоративних прав варто з того, що термін «корпоративне право» притаманний лише правовим системам пострадянських держав. Якщо порівняти національне законодавство 3 особливостями законодавств іноземних держав, то можна помітити той факт, що ані в європейських державах, ані у Сполучених Штатах Америки не існує окремого терміна «корпоративні права». Замість нього законодавство цих держав містить терміни «права акціонера» і «права учасника» [1, с. 173].

Отже, і в цьому варто погодитися з І.В. Лукач, інститут корпоративних прав 
$€$ специфічним, притаманним пострадянській юридичній науці інститутом, який, з огляду на реалії української правової системи, потребує подальших наукових розробок. Зокрема, поняття корпоративного права прийнято розуміти у двох аспектах суб'єктивному й об'єктивному.

Н.С. Глусь визначає корпоративне право в об'єктивному розумінні як сукупність правових норм, які регулюють і охороняють цивільні й інші відносини, що виникають між акціонером, учасником і самою корпорацією, а також між самими учасниками чи акціонерами щодо реалізації їхнього права власності на акцію чи права власності на частку у статутному капіталі корпорації [2]. 3 вищенаведеного можна зробити висновок, що автор включає до об'єктивного корпоративного права також охоронні відносини. Це, зокрема, право акціонера вимагати від товариства викупу його акцій, відповідно до ст. 68 Закону України «Про акціонерні товариства» (далі - ЗУ «Про АТ»), переведення прав i обов'язків покупця акцій/частки у статутному капіталі тощо [3].

Однак не можна погодитися 3 автором в тому, що корпоративне право в об'єктивному розумінні регулює й охороняє «цивільні та інші відносини», адже виникати між акціонерами, учасниками, один з одним і з юридичною особою можуть трудові, фінансові й інші відносини, які не охоплюються нормами корпоративного права. Також не можна погодитися з тим, що такі відносини стосуються суто реалізації права власності на акцію чи частку у статутному капіталі, оскільки реалізація решти корпоративних прав, які становлять об'єкт корпоративних відносин, не зумовлена реалізацією права власності.

Деякі вчені, як-от С.В. Несинова, В.С. Воронко, Т.С. Чебикіна, розглядають об'єктивне корпоративне право як систему юридичних норм, що регулюють групу суспільних відносин, яка виникає у зв'язку зі створенням i функціонуванням юридичних осіб у результаті реалізації суб'єктами цивільних правовідносин права бути їхніми засновниками (учасниками) [4].

На нашу думку, в об'єктивному розумінні корпоративне право - це система правових норм, які регулюють суспільні відносини, що виникають у зв'язку зі створенням, діяльністю та припиненням юридичних осіб, а також набуття та реалізації їх учасниками/акціонерами належних їм корпоративних прав. Річ у тім, що, наприклад, відносини, пов'язані з обігом акцій/часток у статутному капіталі, діяльності юридичної особи безпосередньо не стосуються, як і реалізація учасником/акціонером свого права на отримання інформації про діяльність юридичної особи.

Що ж до суб'єктивних корпоративних прав, коли вони можуть виникати, то думки також різняться.

Одні вчені, серед яких В.А. Васильєва, уважають що під суб'єктивним корпоративним правом варто розуміти суто право участі в господарському товаристві, а всі інші корпоративні права є правомочностями та становлять зміст права участі [5]. Інші вчені, зокрема О.Р. Кібенко, зазначають, що суб'єктивне корпоративне право - це «право осіб вступати в об'єднання, створюючи тим самим нового суб'єкта права; право особи, що виникає з ії членства (участі) у тій чи іншій корпорації» [6]. Така позиція викликає зауваження, і ось чому.

По-перше, згідно з українським законодавством, корпоративні права виникають у зв'язку з участю в юридичній особі. Доки юридичної особи не створено, засновники не набувають корпоративних прав, хоч би ними й зроблено оплату своєї частини статутного капіталу (наприклад, приватне розміщення акцій відбувається до створення акціонерного товариства).

По-друге, в Україні відсутні специфічні типи юридичних конструкцій, щодо яких дійсно можна говорити про наявність корпоративних прав до моменту створення. Якщо О.Р. Кібенко, надаючи визначення суб'єктивному корпоративному праву, намагалася зробити його універсальним, з урахуванням особливостей корпоративного законодавства іноземних держав, то в такому разі іiі думка $є$ слушною, проте водночас $\epsilon$ незастосовною до реалій української правової системи.

Зокрема, іноземний досвід демонструє наявність таких юридичних конструкцій, які дозволяють ще не створеній юридичній особі виступати учасником економічних відносин, набувати прав і обов'язків.

Згідно із законодавством Німеччини, існує юридична конструкція «компанії у процесі створення» (нім. - "Vor-Gesellschaft mit beschr nkter Haftung”) - товариства 3 обмеженою відповідальністю, щодо якого здійснено нотаріальне посвідчення засновницького договору, однак яке ще не зареєстровано в Комерційному (Торговому) реєстрі [7].

За даною конструкцією, товариство 3 обмеженою відповідальністю перебуває на проміжному етапі свого створення, хоч воно, до здійснення запису про реєстрацію в Комерційному (Торговому) реєстрі, юридичною особою, у класичному розумінні даного поняття, не $є$, але законодавство Німеччини надає такому «квазітовариству» 
можливість набувати прав та обов'язків, які зберігають свою чинність для такого товариства і в разі завершення процедури його створення.

Подібну конструкцію можна простежити і в законодавстві Польщі. Зокрема, у ст. 161 Закону «Про комерційні компанії» передбачено можливість існування «компанії у процесі створення» - юридичної особи, відомості про яку ще не внесені до Реєстру компаній, однак щодо якої вже сплачено статутний капітал, викладено на нотаріальному бланку установчий документ (статут) і призначено органи управління. Така компанія може існувати протягом шести місяців і укладати чинні договори [8].

Звісно, існують думки про те, що й згідно з українським законодавством корпоративні відносини включають у себе відносини зі створення юридичної особи [9]. На нашу думку, самі корпоративні відносини, до створення юридичної особи, виникати можуть адже такий висновок, зокрема, можна зробити з аналізу чинного законодавства.

Так, у п. 3 ч. 1 ст. 20 Господарського процесуального кодексу України (далі - ГПК України) названо «спорами, що виникають із корпоративних відносин», ті, що пов'язані зі створенням юридичної особи [10]. Окрім цього, передбачене в ч. 3 ст. 167 Господарського кодексу України (далі - ГК України) визначення дозволяє вести мову про існування корпоративних відносин на етапі створення, бо єдиним критерієм є те, що їхнім об'єктом мають бути корпоративні права, а чи існують вони на даний момент, чи існуватимуть у майбутньому - законодавець не конкретизує [11].

Окрім цього, А.Ю. Смітюх виділяв засновницькі відносини як етап становлення та розвитку корпоративних відносин [12, с. 149]. Однак автор демонструє деяку невизначеність, зазначаючи, що дані відносини є і корпоративними, і «етапом становлення корпоративних відносин», тобто такими, що існують до виникнення корпоративних відносин.

Отже, корпоративні відносини можуть існувати до створення юридичної особи, але корпоративні права на даному етапі виникнути не можуть. Варто наголосити, що право на створення юридичної особи, так зване «засновницьке право», не є корпоративним за своєю природою, адже корпоративні права можуть виникнути лише після створення юридичної особи.

О.В. Бігняк визначає корпоративні права як певний комплекс правомочностей майнового та немайнового характеру, що виникають в учасників корпорацій і юридичних осіб корпоративного типу (квазікорпоративних утворень), що визначаються їхньою майновою участю у статутному (складеному) капіталі відповідних юридичних осіб [13, с. 86].

С.О. Сліпченко визначав корпоративні права як особисті немайнові, зазначаючи, що участь у товаристві є об'єктом особистого немайнового відношення [14]. Така позиція вченого грунтувалася на нині нечинній редакції ст. 100 Цивільного кодексу України (далі - ЦК України) [15], згідно з якою законодавцем було визнано за правом участі в господарському товаристві особистий немайновий характер. Однак навіть із погляду чинного на той час законодавства ані позиція законодавця, ані думка вченого не $є$ правильними, оскільки корпоративні права не відповідають ознакам особистих немайнових прав.

По-перше, не можна зазначати, що вони не $є$ відчужуваними. Так, самі корпоративні права предметом правочинів щодо відчуження не є, однак їх відчуження здійснюється опосередковано, через відчуження частки/ акцій. По-друге, не можна стверджувати що вони не мають економічного змісту, оскільки всі вони так чи інакше пов'язані з отриманням прибутку від діяльності товариства. По-третє, від корпоративних прав, зокрема від права на участь у товаристві, можна відмовитися. Дана можливість, зокрема, закріплена за учасниками товариств з обмеженою та додатковою відповідальністю. Отже, корпоративні права (зокрема, право на участь у товаристві) не відповідають ознакам особистих немайнових прав, за жодних обставин не можуть до них належати.

А.В. Сороченко пропонує власне визначення корпоративних прав, розуміючи під ними «права особи, що у встановленому законом порядку внесла вклад до статутного капіталу господарського товариства, які включають у себе правомочності на участь цієї особи в управлінні господарським товариством, отримання певної частини прибутку такого товариства й активів у разі ліквідації останнього в порядку, передбаченому чинними законодавством, право на одержання інформації про діяльність товариства та інші правомочності, що випливають із закону та/або засновницьких (установчих) документів» [16].

Дане визначення автора є дещо неоднозначним.

По-перше, таке розуміння корпоративних прав звужує коло осіб, яким можуть належати корпоративні права, оскільки прив'язка здійснюється щодо вкладу до статутного капіталу - первинного способу набуття корпоративних прав. Але ж корпоративні права 
можуть набуватися і похідним шляхом, через відчуження однією особою частки/акцій третій особі, звернення стягнення на заставлену частку чи акції тощо. 3 іншого боку, автором слушно вказано на той факт, що корпоративні права можуть бути передбачені як законом, так і засновницькими (установчими) документами, що підтверджується положенням ч. 2 ст. 5 Закону України «Про товариства з обмеженою та додатковою відповідальністю» (далі - ЗУ «Про ТОВ») [17].

По-друге, навіть за неповного внесення свого вкладу така особа все одно набуває корпоративних прав. Згідно зі ст. 14 ЗУ «Про ТОВ», учасник може внести свій вклад протягом шести місяців із моменту створення товариства. Дана норма Закону важлива з огляду на таке. У ст. 14 чітко зазначено, що особа є учасником - набула права участі в товаристві - до повного внесення свого вкладу. Отже, за логікою законодавця, дотримано умову ст. 167 ГК України щодо «особи, частка якої визначена у статутному капіталі», яка є носієм корпоративних прав.

По-третє, використовуючи поняття вкладу, автор фактично залишає поза увагою виникнення корпоративних прав в акціонерних товариствах, оскільки ані ЗУ «Про АТ», ані ГК України не оперують у частині акціонерних товариств поняттям «вклад». Ідеться суто про оплату вартості акцій.

М.К. Богуш зазначає, що запропоноване А.В. Сороченко визначення корпоративних прав не враховує того, що останні виникають виключно в суб'єктів корпоративних відносин (учасників і акціонерів), якими, на думку вченої, не можуть бути треті особи, яким було здійснено відчуження частки/акцій останні, наголошує вчена, є носіями корпоративних прав із моменту набуття права власності на акції товариства чи вступу до ТОВ/ ТДВ, що обов'язково має бути підтверджено рішенням загальних зборів. Із цим обгрунтуванням не можна погодитися з огляду на таке.

По-перше, акція, за своєю правовою природою, є цінним папером, а отже, і порядок набуття прав, засвідчених таким цінним папером, відрізняється від порядку набуття прав, що випливають із частки у статутному капіталі господарського товариства. Згідно із ч. 2 ст. 4 Закону України «Продепозитарну систему» (далі - ЗУ «Про депозитарну систему»), набуття прав на цінні папери (права власності на них), як і прав за цінними паперами, здійснюються шляхом фіксації відповідного факту в системі депозитарного обліку [18].

По-друге, наведена вченою позиція щодо моменту набуття корпоративних прав у ТОВ і ТДВ грунтувалася на абз. 1 п. 2.4, абз. 3 п. 2.6 та п. 2.4 постанови Пленуму Вищого гос- подарського суду України № 4 від 25 лютого 2016 р. «Про деякі питання практики вирішення спорів, що виникають 3 корпоративних правовідносин» (далі - ППВГСУ «Про практику вирішення корпоративних спорів») у якій було зазначено необхідність подання заяви про вступ до товариства, щоби набути статусу учасника [19]. В основі даної позиції Суду була чинна на момент ухвалення постанови ст. 100 Цивільного кодексу України, згідно з якою право участі визнавалося особистим немайновим правом. Сьогодні дана позиція не є актуальною з огляду на внесені зміни до ЦК України у зв'язку з набуттям чинності ЗУ «Про ТОВ».

По-третє, нині внесено зміни до Закону України «Про державну реєстрацію юридичних осіб, фізичних осіб-підприємців та громадських формувань» (далі ЗУ «Про реєстрацію), згідно з якими заява про вступ до товариства відтепер є альтернативним документом, що подається для здійснення реєстрації змін відомостей [20]. На практиці основним документом, який подається для реєстрації змін відомостей, залишається акт приймання-передачі, який, станом натепер, повинен викладатися 3 використанням спеціального бланка нотаріального документа, відповідно до Закону України «Про внесення змін до деяких законодавчих актів України щодо захисту права власності» [21].

По-четверте, Закон не пов'язує момент виникнення права участі у ТОВ або ТДВ із моментом державної реєстрації відповідних змін у складі учасників ТОВ або ТДВ. Даний висновок підтверджується постановою Касаційного господарського суду Верховного Суду від 13 листопада 2018 р. у справі № 910/605/18 [22].

По-п’яте, ЗУ «Про ТОВ» не відносить відомості про розмір часток кожного з учасників ТОВ до обов'язкової інформації, що має міститися у статуті товариства.

Окрім цього, відповідно до п. 17 Модельного статуту товариств 3 обмеженою відповідальністю, затвердженого постановою Кабінету Міністрів України від 27 березня 2019 р. № 367, вступ до товариства здійснюється шляхом придбання (набуття) третьою особою частки (частини частки) у статутному капіталі товариства або в порядку спадкування (правонаступництва) [23]

Отже, набуття корпоративних прав у ТОВ і ТДВ пов'язується 3 моментом набуття права власності на частку у статутному капіталі, тоді як право власності на акції та корпоративні права за ними виникають із моменту внесення відомостей до депозитарної системи. 
Визначення поняття корпоративних прав, надане законодавцем у ст. 167 ГК України, також не є досконалим. У даній правовій нормі зазначено лише їх перелік і той факт, що вони належать особі, частка якої визначається у статутному капіталі господарської організації. Ми вважаємо, що підхід законодавця загалом до визначення корпоративних прав потребує вдосконалення та внесення змін з огляду на таке.

В економічно розвинених країнах давно поширений такий феномен, як існування номінальних акціонерів/учасників і бенефіціарних власників. Приклади його існування можна знайти і в Україні. Під номінальним акціонером/учасником варто розуміти особу, яка де-юре зазначена власником акцій у статуті, реєстрах та інших документах. У свою чергу, бенефіціарним власником $є$ особа, яка з тих чи інших причин вирішила зберегти анонімність, для чого призначає особу (фізичну чи юридичну), яка буде діяти в її інтересах. Пстає питання, кому належать корпоративні права - номінальному акціонеру учаснику чи особі, в інтересах якої він діє?

Якщо звернутися до досвіду країн англосаксонської правової сім'ї, то відносини між номінальним акціонером/учасником і бенефіціарним власником оформлюються трастовою декларацією (трастовою угодою). Тобто йдеться про інститут довірчої власності в тому розумінні, у якому він існуе в даній правовій сім'ї.

За трастовою угодою номінальний акціонер/учасник підтверджує, що корпоративні права - право голосування, право на отримання дивідендів тощо - та повноваження власника належать не йому, а бенефіціарному власнику, за вказівками якого номінальний акціонер/учасник буде їх реалізовувати [24].

Отже, де-юре власником акцій («особою, частка якої визначена у статутному капіталі») є номінальний акціонер/учасник, однак де-факто власником і особою, яка наділена корпоративними правами та повноваженнями власника, є саме бенефіціарний власник.

Однак, згідно з легальним визначенням корпоративних прав, запропонованим у ГК України, дані права мали б належати номінальному акціонеру, адже, 3 формальноюридичного погляду, саме він є власником акцій у статутному капіталі. Це видається очевидним, якщо звернути увагу на положення ч. 2 ст. 4 ЗУ «Про депозитарну систему», за яким набуття, зміна та припинення прав за цінними паперами (зокрема, за акціями) обумовлена внесенням відповідного запису до депозитарної системи обліку цін- них паперів. Отже, даний підхід законодавця не повною мірою враховує сучасні тенденції у сфері корпоративного права.

3 огляду на те, що визначення корпоративних прав у ГК України містить прив'язку саме до участі в юридичній особі, а не тільки права власності на частку у статутному капіталу, а також той факт, що, згідно із ЗУ «Про TOB», корпоративними правами наділені саме учасники, доцільніше буде говорити, що в разі існування відносин номінального учасика/акціонера та бенефіціарного власника відбувається не управління корпоративними правами останнього, а радше реалізація номінальним учасником/акціонером його корпоративних прав (саме він є їхнім носієм) в інтересах бенефіціарного власника.

ЗУ «Про АТ» демонструє більш прогресивну позицію законодавця в питанні визначення корпоративних прав. У п. 111 ст. 2 Закону «Про АТ» передбачено поняття «опосередкованого набуття власності». Під цим терміном, у цілях Закону, розуміється, зокрема, «набуття права власності, що настає, якщо особа самостійно або спільно з іншими особами, зокрема, здійснює контроль прямого власника акцій акціонерного товариства та/або здійснює контроль групи прямих власників акцій акціонерного товариства <..>>. Інакше кажучи, у визначенні прямо йдеться про те, що у відносинах між номінальним акціонером і бенефіціарним власником останній опосередковано набуває право власності, яке, у свою чергу, є підставою для набуття корпоративних прав.

Отже, введення законодавцем поняття «опосередковане набуття власності» $є$ тим самим уточненням, яке дозволяє поєднати власність як підставу для виникнення корпоративних прав і феномен існування номінальних акціонерів та бенефіціарних власників. Зазначене, у свою чергу, дозволить визнавати бенефіціарного власника частки/ акцій у статутному капіталі суб'єктом корпоративного спору, адже сьогодні ГПК України, згідно 3 п. 3 ч. 1 ст. 20, під корпоративними спорами розуміє ті, що виникають із корпоративних відносин між учасниками юридичної особи чи між юридичною особою та її учасниками (засновники, акціонери, члени), учасником, що вибув.

Але успіх законодавця в даному аспекті породжує нові проблеми. Адже поняття «опосередковане набуття власності» ужито лише в цілях регулювання відносин щодо акціонерних товариств, тоді як номінальними власниками можуть бути й учасники у статутних капіталах інших господарських товариств, зокрема товариств 3 обмеженою та додатковою відповідальністю. 
Тому, на нашу думку, визначаючи поняття суб'єктивного корпоративного права, доцільно було б внести зміни до ст. 167 ГК України, виклавши ч. 1 в такій редакції: «Корпоративні права - це права, що належать власнику частки у статутному капіталі (майні) господарської організації або особі, яка опосередковано набула право власності на таку частку, що включають право на участь цієї особи в управлінні господарською організацією, отримання певної частки прибутку (дивідендів) даної організації та активів у разі ліквідації останньої відповідно до закону, а також інші права, передбачені законом та статутними документами».

Також ч. 1 ст. 167 ГК України пропонується доповнити абз. 2, який повинен містити визначення опосередкованого набуття права власності, відтворюючи зміст, викладений у п. 111 ст. 2 ЗУ «Про АТ».

Варто зазначити, що існує виняток із загального правила щодо того, що корпоративні права належать особі, яка набула (опосередковано набула) право власності на частку (майно) у статутному капіталі. Так, особа, яка припинила свою участь у товаристві з обмеженою чи додатковою відповідальністю шляхом виходу, зберігає за собою корпоративне право на одержання вартості частки, що їй належала, водночас виплата вартості частки може бути здійснена товариством, згідно із ч. 7 ст. 24 ЗУ «Про ТОВ», протягом одного року із дня, коли воно дізналося чи мало дізнатися про вихід учасника, якщо інший строк не встановлено статутом.

Винятком із загального правила $€$ і набуття корпоративних прав спадкоємцями, передбачене у ст. 23 ЗУ «Про ТОВ». 3 моменту відкриття спадщини і до моменту подання заяви про вступ учасником залишається спадкодавець, а прийняття спадщини (частки) не зумовлює виникнення у спадкоємців корпоративних прав, доки ними не буде подано заяву про вступ.

Також варто розглянути правову природу суб'єктивного корпоративного права. Зокрема, можна звернутися до праць Ф.К. фон Савіньї, Молля та Міттенмайера, які обстоювали думку, що корпоративне право (акціонерне право) по суті має подвійну правову природу - з одного боку, йдеться про право речове (спільна власність), а з іншого про право співучасті [25].

Станом натепер некоректно говорити про спільну власність учасників/акціонерів, оскільки з моменту внесення вкладу до статутного капіталу власником переданого майна стає юридична особа, про жодну співвласність не йдеться. Учасники ж набувають відповідних часток у статутному капіталі, які є самостійними оборотоздатними об'єктами та належать кожному з них за правом власності. Але й заперечувати речовий характер низки корпоративних прав також не варто. Ідеться про такі права, як право власності на частку/акції у статутному капіталі, право вимагати викупу акцій, право на отримання майна під час ліквідації товариства тощо.

C.В. Батрин, характеризуючи правову природу корпоративних відносин, зазначав їхню речово-правову природу, виходячи з того, що їх виникнення й існування зумовлено реалізацією власником правомочностей володіння, користування та розпорядження майном посередництвом участі в корпоративному господарюванні [26]. Отже, можна дійти висновку, що і правова природа корпоративних прав, на думку С.В. Батрина, $\epsilon$ речовою.

На нашу думку, така позиція вченого є дещо категоричною, адже як не самі корпоративні відносини, так і не всі корпоративні права опосередковуються правомочностями володіння, користування та розпорядження. Так, наприклад, ані право участі в управлінні товариством, ані право на одержання інформації про діяльність товариства не є речовоправовими, а їх реалізація не пов'язана зі здійсненням власником акцій/частки у статутному капіталі правомочностей володіння, користування та розпорядження. Отже, хоча зазначені права і випливають, згідно із законодавством, із факту набуття права власності на акції/частку у статутному капіталі, говорити про виключно речово-правову природу корпоративних відносин, зокрема корпоративних прав, що становлять їхній об'єкт, є дещо некоректним.

На противагу вищезазначеній позиції можна навести думку Т.В. Кашаніної, яка зауважує, що корпоративні права мають змішаний характер. Учена виділяє суто корпоративні права - «право на участь в управлінні товариством», та зобов'язальні права - «право на належну акціонеру частину майна, що залишилася після ліквідації акціонерного товариства» [27]. Такої ж думки - щодо виділення суто корпоративних прав і зобов'язальних - дотримується й О.В. Щербина [28].

На наш погляд, говорячи про корпоративні права та їхню правову природу, варто визначати комплексність даного явища, оскільки воно не вичерпується лише одним iз його аспектів, сутнісно проявляється по-різному, залежно від виду корпоративного права, що є предметом розгляду. Зокрема, корпоративні права мають речовоправову (право розпоряджатися своєю часткою/акціями), зобов'язальну (право на диві- 
денди) та власне корпоративну природу (право на участь в управлінні, право на отримання інформації).

Розгляд питання правової природи корпоративного права буде неповним, якщо не розглянути, домінування якої концепції - унітарного єдиного права чи множинності прав - лежить в основі даного суб'єктивного права.

Зокрема, I.T. Тарасов, який досліджував корпоративні права акціонерів ще в часи Російської імперії, наголошував на невід’ємності правомочності акціонера бути обраним від його права на участь в управлінні акціонерним товариством. Однак водночас учений класифікував корпоративні права (а не правомочності) на основні та спеціальні, де основними були: 1) право на частину акціонерного капіталу в разі ліквідації AT; 2) право на участь в управлінні; 3 ) право контролю; 4) право на отримання частини прибутку; 5) право скарги, позову та протесту. Спеціальними ж були всі решта.

Отже, учений, імовірно, схилявся до існування множинності корпоративних прав, визначаючи нерозривний зв'язок між окремими з них і тими правомочностями, що становлять їхній зміст.

В.А. Бєлов, будучи прихильником концепції єдиного корпоративного права, зазначав, що будь-яке правовідношення може складатися лише 3 одного суб'єктивного права й одного юридичного обов'язку, який йому кореспондує [29].

Досить неоднозначний підхід, адже для правовідносин характерна наявність у них також множинності прав і обов'язків. Для ілюстрації сказаного за приклад можна взяти зобов'язальні відносини з договору підряду. Підрядник має право на: 1) оплату роботи; 2) ощадливе ведення робіт тощо. Аналогічна ситуація із множинністю обов'язків.

Окрім цього, варто зазначити, що концепція єдиного корпоративного права також спирається на той факт, що законодавець у ч. 1 ст. 167 ГК України та п. 8 ч. 1 ст. 1 ЗУ «Про АТ» визначає корпоративні права через одночасне застосування термінів «право» (сукупність прав) і «правомочність». Однак вищезазначені норми передусім акцентують увагу на тому, що корпоративні права як сукупність складаються з низки окремих одиничних прав, що є правильним підходом.

Також досить неоднозначний той факт, що, за концепцією єдиного корпоративного права, ми стикаємося із ситуацією, коли таке право не матиме єдиного змісту - останній буде встановлюватися в кожному конкретному випадку. Даний висновок випливає 3 положень п. 3 ч. 1 ст. 24 ЗУ «Про АТ» і ч. 2 ст. 5 ЗУ «Про ТОВ», якими передбачено можливість учасників мати й інші права, передбачені статутом товариства.

Продовжуючи, варто зазначити, що прихильники концепції єдності корпоративного права визначають решту юридичних можливостей суб'єктів корпоративних відносин як правомочності. 3 таким поглядом погодитися складно. Адже в такому разі правомочності суб'єктів корпоративних відносин складатимуться із власної сукупності юридичних можливостей, «субправомочностей». Наприклад, якщо вести мову про участь в управлінні товариством, то така правомочність складатиметься з таких елементів: 1) правомочність скликати загальні збори; 2) правомочність голосувати особисто чи через представника; 3) правомочність вносити питання на розгляд загальних зборів; 4) правомочність бути обраним до органів управління товариства.

Отже, про корпоративні права варто говорити в їхній множинності, а не універсальній єдності (єдине ціле), що складається із правомочностей, оскільки доходимо до абсурду, коли правомочності складаються 3 низки власних правомочностей.

Загалом, варто погодитися в цьому питанні 3 I.В. Лукач, яка, розглядаючи питання єдності чи множинності корпоративних прав, дотримується думки, що дана дискусія була створена в науковому середовищі штучно, визначає корпоративні права через їхню множинність, зазначаючи, що під ними варто розуміти «права учасників корпорації, що виникають у результаті участі у статутному капіталі на підставі правової норми».

\section{Висновки}

У результаті проведеного дослідження варто зазначити таке:

- корпоративні права $є$ досить складним юридичним явищем, запровадженим пострадянською наукою, яке не є притаманним законодавствам іноземних держав поза пострадянським простором;

- незважаючи на те, що у світі існують юридичні конструкції «товариств у процесі створення», їх існування не передбачено українським законодавством, а тому корпоративні права не можуть існувати до моменту створення даної юридичної особи;

- корпоративні права набуваються разом із набуттям права власності на частку чи акції у статутному капіталі. Виняток - вступ до товариства спадкоємців;

- відносини щодо створення юридичної особи є засновницькими - різновидом корпоративних відносин, але право на створення юридичної особи корпоративним не є; 
- чинне законодавство дозволяє розглядати бенефіціарного власника як суб'єкта корпоративних відносин і корпоративних спорів лише в частині регулювання акціонерних товариств. Тому пропонується запровадити даний підхід щодо інших юридичних осіб, шляхом внесення змін до корпоративного законодавства;

- корпоративні права мають складну правову природу. Залежно від того, яке саме корпоративне право є предметом розгляду, корпоративні права мають речово-правову, зобов'язальну та власне корпоративну природу;

- корпоративні права слід розглядати як множинність, а не як універсальну єдність.

\section{Список використаних джерел:}

1. Лукач І.В. Господарсько-правове регулювання корпоративних відносин в Україні: теоретичні проблеми : дис. ... докт. юр. наук: 12.00.04. Київ, 2016. 474 с

2. Глусь Н.С. Корпорації та корпоративне право: поняття, основні ознаки та особливості захисту : автореф. дис. ... канд. юрид. наук: 12.00 .03$. Київ, 2000. 23 с.

3. Про акціонерні товариства : Закон України, у редакції від 17 жовтня 2019 р. Відомості Верховної Ради Украӥни. 2008. № № 50-51. Ст. 384.

4. Господарське право України : навчальний посібник / за заг. ред. С.В. Несинової. Київ : Центр учбової літератури, 2012.564 c.

5. Шевчук О.Р., Бобер С.Ю. Корпоративні права учасника господарського товариства: проблеми правової регламентації. Актуальні проблеми правознавства. 2018. № 4. С. 186-190.

6. Кибенко Е.Р. Корпоративное право : учебное пособие. Харьков : Эспада, 1999. 480 с.

7. Schneider G., Stefano M. Doing business in Germany. 2014. URL: https://www.tiefenbacher. de/fileadmin/tiefenbacher_neu/seiteninhalt/ broschueren/Doing_Business_in_Germany.pdf.

8. Кодекс комерційних компаній Польщі, затверджений постановою Сейму від 15 вересня 2000 p. URL: https://supertrans2014.files.wordpress. com/2014/06/the-commercial-companies-code.pdf.

9. Пальчук П.М. Корпоративне право : навчальний посібник. Київ : Київ. нац. торг.-екон. ун-т, 2015. $316 \mathrm{c.}$

10. Господарський процесуальний Кодекс : Закон України, у редакції від 16 листопада 2019 р. Відомості ВерховноїРади України. 1992. № 6. Ст. 56.

11. Господарський кодекс : Закон України, у редакції від 17 листопада 2019 р. Відомості Верховної Ради Украӥни. 2003. № № 18-22. Ст. 144.

12. Смітюх А.В. Корпоративні права та корпоративні паї (частки): теоретико-правові засади:автореф.дис....докт.юр. наук: 12.00.04. Київ, 2019. 37 c.

13. Бігняк О.В. Цивільно-правовий захист корпоративних прав в Україні : дис. ... докт. юр. наук: 12.00.03. Одеса, 2018. 474 с.
14. Сліпченко С.О. Особисті немайнові відносини щодо оборотоздатних об'єктів. Харків, 2013. $498 \mathrm{c}$.

15. Цивільний кодекс : Закон України, у редакції від 28 листопада 2019 р. Відомості Верховної Ради Украӥни. 2003. № № 40-44. Ст. 356.

16. Сороченко А.В. Корпоративні права та обов'язки: господарсько-правовий аспект : автореф. дис... канд. юр. наук: 12.00 .03 . Київ, 2015. 20 с.

17. Про товариства з обмеженою та додатковою відповідальністю : Закон України, у редакції від 2 листопада 2019 р. Відомості Верховної Ради України. 2018. № 13. Ст. 69.

18. Про депозитарну систему : Закон України, у редакції від 18 жовтня 2019 р. Відомості Верховної Ради України. 2013. № 39. Ст. 517.

19. Про деякі питання практики вирішення спорів, що виникають 3 корпоративних правовідносин : постанова Пленуму Вищого господарського суду України № 4 від 25 лютого 2016 р. Офіиійна інтернет-сторінка Верховної Ради України. URL: https://zakon.rada.gov.ua/laws/ show/v0004600-16.

20. Про реєстрацію юридичних осіб, фізичних осіб-підприємців та громадських формувань : Закон України, у редакції від 2 листопада 2019 р. Відомості Верховної Ради України. 2003. № № 31-32. Ст. 263.

21. Про внесення змін до деяких законодавчих актів України щодо захисту права власності : Закон України, у редакції від 3 жовтня 2019 р. Відомості Верховної Ради України. 2019. № 47. Ст. 312.

22. Постанова Касаційного господарського суду Верховного Суду від 13 листопада 2018 р. у справі № 910/605/18. Офіиійна інтернет-сторінка Єдиного державного реєстру судових рішень. URL: http://www.reyestr.court.gov.ua/ Review/77821192.

23. Деякі питання дерегуляції господарської діяльності : постанова Кабінету Міністрів України від 27 березня 2019 р. № 367

24. Kourtellos P.N. Nominee shareholders - valid trust arrangements or a mere façade? Mondaq. 2015 URL: http://www.mondaq.com/cyprus/x/399568/ Shareholders/Nominee+shareholders+valid+trusts + arrangements + or $+\mathrm{a}+$ mere+faade.

25. Тарасов И.Т. Учение об акционерных компаниях. Москва : Статут, 2000. 666 с.

26. Гарагонич О.В. Правова природа корпоративних відносин між акціонерами та акціонерним товариством. Часопис иивільного $і$ кримінального судочинства. 2016. № 3. С. 130-141.

27. Кашанина Т.В. Корпоративное право (Право хозяйственных товариществ и обществ) : учебник для вузов. Москва : Норма - Инфра-М 1999. C. 419

28. Щербина О.В. Правове становище акціонерів за законодавством України. Київ : ЮрінкомIнтер, 2001. C. 22

29. Корпоративное право: актуальные проблемы теории и практики / под. общ. ред. В.А. Белова. Москва : Юрайт, 2009. 678 с. 
The article is devoted to analysis of corporate rights' concept and their legal nature. The author studies doctrinal approaches to understanding of subjective and objective corporate rights, highlighting shortcomings of such approaches and providing his own definitions. Deeming of corporate rights as personal non-property rights has been disagreed with due to them having no signs of the latter. Emphasis has been made on the differences in the acquisition of corporate rights arising from the share in the charter capital and the shares of the company. In both cases corporate rights derive from the ownership right, but regarding shares of the company both corporate rights and ownership arise simultaneously - from the moment the information has been entered into a uniform depository system. Phenomena of founding right has been studied. Emphasis has been made on not being able to attribute this right to corporate rights due to latter arising only once a legal entity has been established. However, legal relationships, related to the exercise of the founding right, should be considered corporate. The article also explores the peculiarities of foreign legislations regarding the possibility of the existence of legal entities «in the process of creation», corporate rights in which may arise before their creation. Analysis of corporate rights has also been made through nominal shareholders' phenomena. It has been concluded, that current legislation depicts fragmentary approach when it comes to regulation of this phenomena - of all legal entities, only in joint-stock companies a beneficial owner can be a party to corporate relations. Thus, it is suggested to amend the current legislation, providing for the definition of corporate rights not only to arise from ownership but also from indirect acquisition of ownership, similarly with joint stock companies. The author also considers the matter the legal nature of corporate rights, noting the mixed nature of the latter, despite them arising from the ownership of the shares / share in the charter capital. It is also proposed to consider corporate rights from the point of view of their multiplicity, rather than a single corporate right, which consists of powers and sub-powers.

Key words: corporate rights, power, founder's right, shares, participatory interest, charter capital. 